\title{
BIOCHEMICAL ANALYSIS OF SOME DRIED SIS FISHES OF THE RIVER PADMA IN RAJSHAHI
}

\author{
Sabina Sultana*, Selina Parween, M. Altaf Hossain
}

\author{
Fisheries Research Laboratory, Department of Zoology, University of Rajshahi, Rajshahi 6205, \\ Bangladesh \\ *Corresponding author (e-mail: seager18@yahoo.com)
}

\begin{abstract}
Seven different species viz. Chanda baculis, Chanda ranga, Amblypharyngodon mola, Oxygaster bacaila, Clupisoma atherinoides, Corica soborna, Mystus vittatus and a group of mixed SIS fishes viz. Mastacembelus pancalus, Xenntodon cancila, Chanda baculis and Glossogobius giuris were used for preparation of dust which can be preserved for a time period. The fishes were sun dried or oven dried, which are also method of preservation. Quality of the oven-dried fish was better than that of the sun-dried fish, but sun-drying process is easy and can be used in large scale. The fish powder remained in good condition for 7-9 months at normal room temperature, but at $-18^{\circ} \mathrm{C}$ the powder was in good condition throughout the year. Highest quantity of powder from $1 \mathrm{~kg}$ of fish was obtained in case of the mixed species as $24.61 \%$ and the lowest in 0 . bacaila which was $20.52 \%$. Biochemical analysis showed that the maximum calcium content was found as $1.34 \%$ in $M$. vittatus and minimum was $0.80 \%$ in mixed SIS fishes. Maximum phosphorus content was $2.90 \%$ in C. ranga and minimum was $1.72 \%$ in C. soborna. Maximum iron content was found as $45.20 \mathrm{mg} / 100 \mathrm{~g}$ in mixed SIS fishes and minimum was found as $16.85 \mathrm{mg} / 100 \mathrm{~g}$ in O. bacaila. The maximum moisture content was found in C. ranga (13.50\%) and the minimum in mixed SIS fishes (11.65\%). The maximum protein content was recorded in the mixed SIS fishes (72.45\%) and the minimum in C. ranga (52.65\%). The experiment was replicated three times and conducted from July 2005 to July 2008.
\end{abstract}

Key words: Nutrient, biochemical, SIS, Padma.

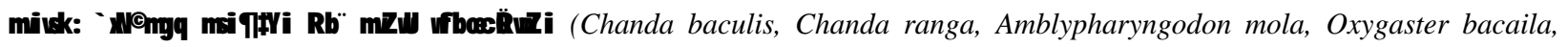
Clupisoma atherinoides, Corica soborna, Mystus vittatus) Ges GK 'j vg k $\mathrm{a} Q \mathrm{WW} g \mathrm{~g}$ (Mastacembelus pancalus, Xenntodon cancila,

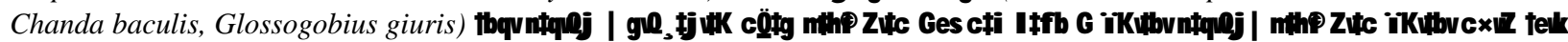

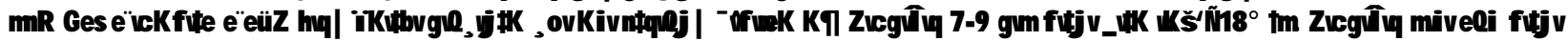

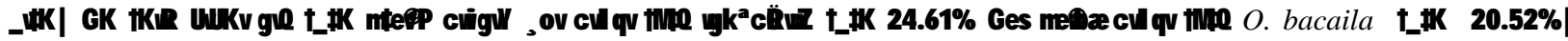

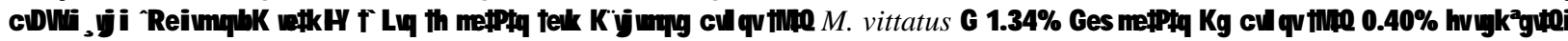

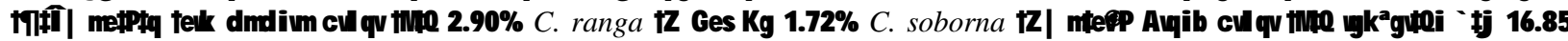

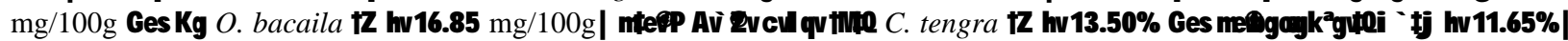

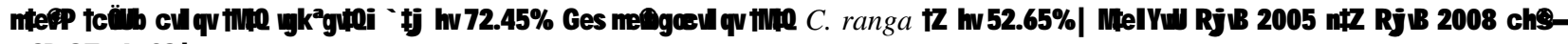

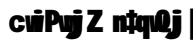

\section{Introduction}

Throughout the world, it is well accepted that fishes are good sources of animal protein and other elements for the maintenance of healthy body (Andrew, 2001). Fish flesh contains up to $15-25 \%$ protein, $80 \%$ water, 12\% mineral matter (CSIR, 1962). FAO 1991 report shows that fishes contain $72 \%$ water, $19 \%$ protein and $5 \%$ calcium. In terms of weight of food consumed, fish ranks third after rice and vegetables (Minkin et al., 1997 and Hels et al., 2002). The protein content of fishes ranges from 14 to 18g/100g raw edible parts (DarntonHill et al., 1988). From the last national survey in rural Bangladesh, the mean total protein intake was 48g/person/day, of which fish contributed 3g (Ahmad and Hassan, 1983). Besides protein source, small indigenous species (SIS) of fishes are also a rich source of vitamins and minerals, which is often overlooked in developing countries (Hossain and Afroze, 1991; Roos et al., 2007).

The Small Indigenous Species (SIS) of fishes in Bangladesh are generally considered to be those which grow to a length of approximately $5-15 \mathrm{~cm}$ at maturity (Felts et al. 1996). Detailed biological information of these species is scanty, but important data are available on culture and biology of Mola fish (A. mola) and some other related species. The SIS fishes have short life cycle and can grow in all types of inland water bodies. Because of overfishing in inland water bodies and habitat destruction, a number of small fishes are now under the threat of extinction. In Bangladesh 143 
freshwater fish species are categorized as small indigenous fishes. In the past, these fishes were abundant in the rivers, beels, canals, streams and ponds. So, presently there is an urgent need to conserve the SIS fish and to increase their production through proper management of the water bodies of Bangladesh. Side by side these species should be introduced in the farming systems of the country.

Thilsted et al. (1997) and Roos et al. (2007) reported that vitamin A, calcium, iron and zinc are present in commonly consumed small fish species of Bangladesh. Very high content of vitamin A (500-1500 $\mu \mathrm{g}$ RE/100g raw edible parts) are obtained from Dhela (Osteobrama cotio cotio), Darkina (Esomus danricus), mola and chanda (C. baculis) (Roost et al., 2003). The sun-dried SIS fishes contain up to $60-80 \%$ protein (Hoq, 2004). A good number of works on nutrient composition of freshwater fishes of Bangladesh have been done by different researchers viz., Gheyasuddin et al. (1979), Kamaluddin et al. (1977), Mazumder et al. (2008), Naser et al. (2007) and Rubbi et al. (1987) but very little attention has been paid on the proximate composition of nutrients which are present in dried fishes or dry fish dust.

Because the importance of SIS fishes is growing among all classes of consumers, some of these species are presently included in the aquaculture system. During the peak fishing time, when large quantities of SIS fishes are caught, these fishes are sun-dried. Major amount of these sun-dried SIS fishes are consumed inside the country and a smaller portion is exported. Owing to the lack of reports on the nutritional values of the dried fish, the present work was aimed at estimating the nutritional value of the dried fish dust and/or powder of some selected SIS fishes of the country.

\section{Materials and Methods}

Fish species used: Seven small fish species namely Chanda baculis, Chanda ranga, Amblypharyngodon mola, Oxygaster bacaila, Clupisoma atherinoides, Corica soborna, and Mystus vittatus were used separately. In addition, a group of mixed SIS fishes viz. Mastacembelus pancalus, Xenntodon cancila, Chanda baculis, Glossogobius giuris were also used in the experiment.

Collection of fish and estimation of the nutrient components: The experimental fishes were collected afresh from July 2005 to July 2008 from different fish markets of Rajshahi City Corporation and experimental ponds. Soon after collection, the fishes were brought to the Fisheries Research Laboratory, Department of Zoology, Rajshahi University, washed carefully with tap water and the waste materials were discarded. After cleaning the species were isolated and depending on size sun-dried up to 4-7 days under fly nets. Using an electric blender the dried fishes were then powdered species wise and kept in separate airtight glass containers with proper labeling. The biochemical tests of the powered samples were done in July 2008.

Calcium (\%) was determined by precipitating method while phosphorous and iron were determined calorimetrically. Moisture content (\%) was determined by drying the material at $110^{\circ} \mathrm{C}$. Quantitative determination of protein was done following Kjeldhal method, and that of fat was done following the methods described by Cocks and van Reda (1966) and Mehlenbacher (1960). The biochemical analysis was done in the laboratory of the Institute of Food and Technology, Bangladesh Council of Scientific and Industrial Research (BCSIR), Dhaka. The experiment was conducted during a period from July 2007 to July 2008.

\section{Results and Discussion}

Depending on the species, results showed a wide variation in proximate composition of calcium, phosphorous, iron, protein, fat and moisture present in the dried samples (Figs. 1a-1f). Among the mineral contents, calcium was found to range from $0.80 \%$ (mixed species) to $1.22 \%$ in $C$. baculis. The highest amount of phosphorus was found in C. ranga (2.90\%) and the lowest was found in C. soborna (1.72\%). Maximum amount of iron was found in mixed species (45.20/100g) and the least amount was found in $C$. atherinoides (16.85mg/100g). Moisture content was high in C. ranga (13.50\%) and low in mixed species (11.65\%). The highest percent of protein content was found in the mixed species $(72.45 \%)$ and lowest was found in C. ranga (52.65\%). The fat content was maximum (23\%) in mixed species and minimum (12.66\%) in C. soborna. The results revealed that $C$. soborna contained less fat and Chanda species were less proteneous compared to mola, tengra and gharua. $C$. baculis, A. mola and $M$. vittatus were rich in calcium. Phosphorous was minimum in $C$. coborna and $C$. atherinoides. Whereas, iron was less in $C$. ranga and $O$. bacaila compared to others. The percentage of moisture was more or less same in all the experimental fishes. 
According to the works of Kamal et al. (2007), Mazumder et al. (2008) and Musa (2009) the nutritional values of the SIS fishes are richer compared to the larger fish species. As these fishes are caught from

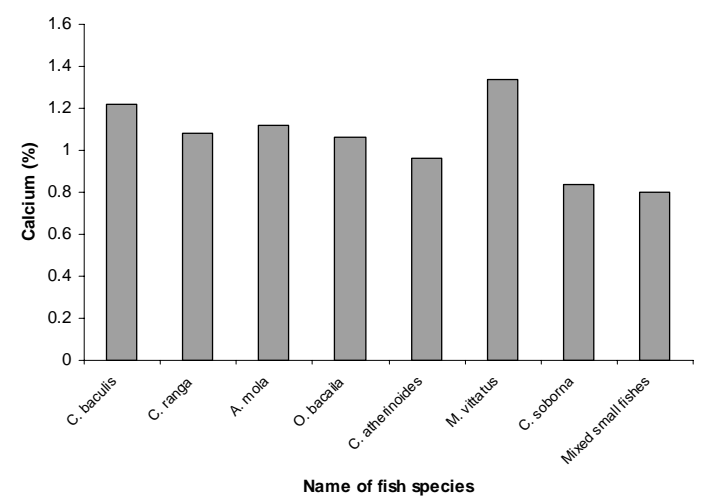

Fig. 1a. Percentage of calcium in the SIS fishes

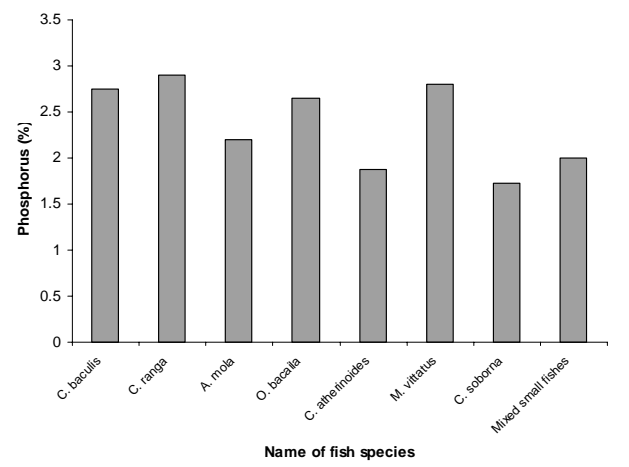

Fig. 1c. Percentage of phosphorus SIS fishes

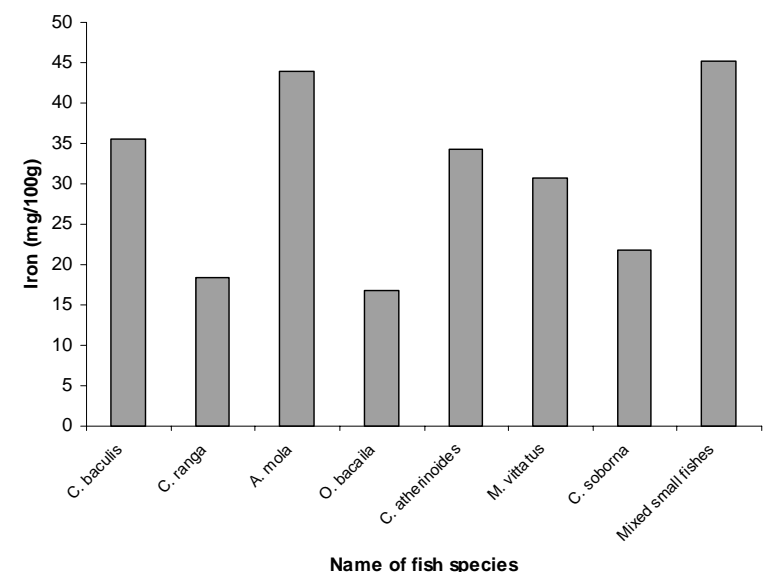

Fig. 1e. Percentage of Iron in the SIS fishes. common property resources and 'Khash' (government owned) water bodies, provide an important source of income and nutrition for rural landless people (Mazumder and Lorenzen 1999).

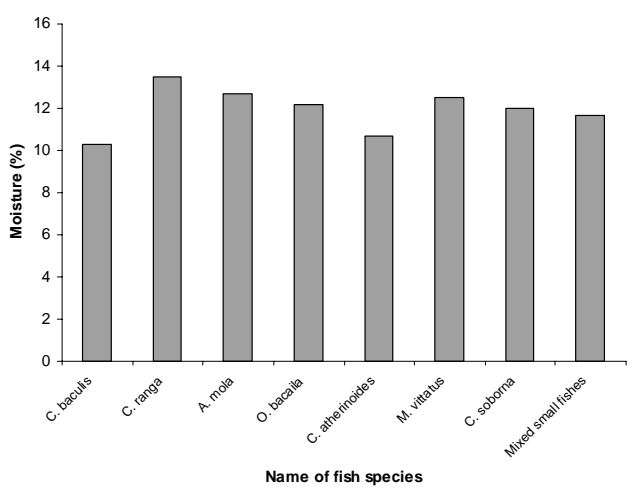

Fig. 1b. Percentage of moisture in the SIS fishes

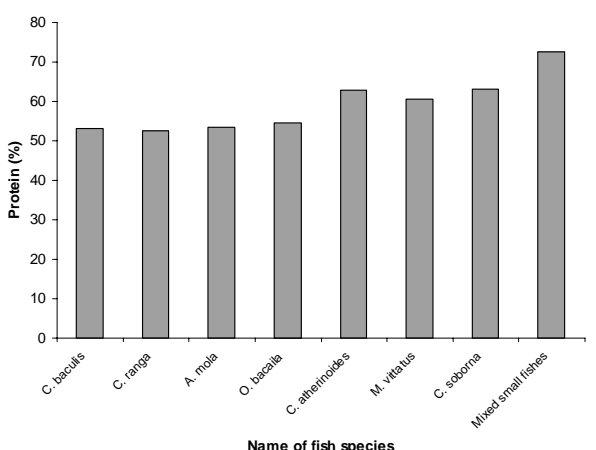

Fig. 1d. Percentage of protein in the SIS fishes.

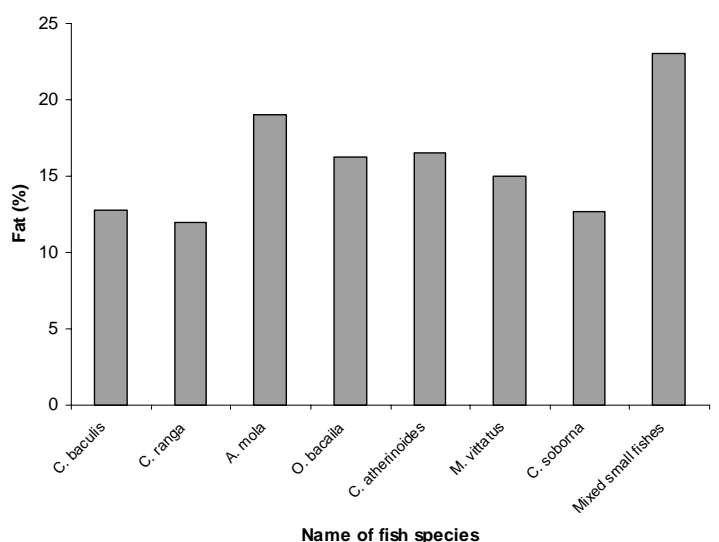

Fig. 1f. Percentage of fat in the SIS fishes. 
The biochemical analysis of nutrient composition shows that the dried SIS fishes used in the experiments are rich in protein containing 52.66 to $72.45 \%$; from $12-23 \%$ fat was obtained in these dry fishes. These dried fishes were also rich in iron and contained good amount of calcium and phosphorous. Calcium plays essential role in human body for the formation of bones muscle tone and nervous impulse (Mollah et al., 1998). It has been reported that Cirrhina reba contains $822 \mathrm{mg}$ calcium/100g of fish (Islam et al., 2003), species like Gudusia chapra, Channa punctatus and A. mola contain 1063, 1093 and $1171 \mathrm{mg} \mathrm{Ca} / 100 \mathrm{~g}$, respectively of raw edible parts (Roos et al., 2003). As SIS fishes are consumed totally along with bones, so there is no wastage of calcium from these fishes. Phosphorous is another essential nutritional element for human, which is also present at a high percentage in the tested fishes.

The moisture of all living systems contributes as much to the essential properties of life. After drying the moisture remained in the fish dust, which ranged from $11.65-13.50 \%$ in different species. More or less similar result was reported by Azam et al. (2003). The authors found in 14 dried fish species, moisture content varied from 18.23 to $23.61 \%$. Saha (1999) also reported that sun-dried SIS fishes contained 36.50 to $82.80 \%$ moisture. Nurullah et al. (2003) reported that moisture ranged from 72.97 to $76.35 \%$ in six SIS fishes, the highest moisture content was in G. chapra and the lowest in P. sarana. Sun-dried G. chapra contains 9.6118.64\% moisture (Bhattacharyaya et al., 1985). Hoq (2004) reported that normally the sun-dried fishes contain an average of 10 to $20 \%$ moisture.

The mixed fish dust contained the highest percentage of protein (72.45\%). Among the tested fishes C. ranga is less proteinous. Protein content varies among the species according to their food habit, and Azam et al. (2003) found that the values ranged from 6.52 to $40.69 \%$ in 14 species of dried fishes. Hoq (2004) concluded that normally the sun-dried fishes contain 60 to $80 \%$ protein. Fat content also varies among the species of SIS fishes. Hussain et al. (1992) obtained 3.7 to $17.8 \%$ fat in 23 sun-dried fish species. In the present experimental fishes more or less equal amount of fat was obtained. C. soborna contained the minimum fat (12.66\%) whereas the dust of mixed species contained a higher percentage of fat (23\%).

In present dried fishes were found to contain iron ranging from $16.85 \mathrm{mg} / 100 \mathrm{~g}$ fish (O. bacaila) to 45.20 $\mathrm{mg} / 100 \mathrm{~g}$ fish (mixed species). Nurullah et al. (2003) reported that iron was present at a range from 14.50 to
$42.20 \mathrm{mg} / 100 \mathrm{~g}$ of raw fish, and Chapila (G. cahpra) contained the highest amount of iron among the studied SIS fishes. Esomus danricus, A. mola, G. chapra, M. vittatus, etc. were rich in iron, but the SIS fishes normally present in the fish culture ponds of Bangladesh are low in iron and calcium content and NCR (Nutrient Contribution Ratio) value of these fishes were all low as $<5 \%$ (Roos et al. 2003).

The results of the present study provided the information that the dried or powdered SIS fishes are equally nutritive as they are in fresh condition. The protein content was more than $50 \%$, with rich supply of iron, calcium and phosphorous (the essential minerals for human growth and life). So, for the nutritional security, SIS fishes should be grown in every possible water bodies, and also along with the cultured fishes in the fish culture system. During the peak season (monsoon and post-monsoon), at distant rural areas of northern districts of Bangladesh, SIS fishes are captured at such an amount that a part of the catch were wasted because of their small size, soft body, absence of preservation method during transportation to a long way (Parween et al. 1997). In such circumstances these fishes can be sun-dried and stored, and consumed for longer period. Similar to fresh fishes, these dry SIS fishes will provide equal nutrition. So, SIS fishes in dry or fresh condition can play role in the nutritional security for the rural people of low income groups.

Acknowledgements: The authors are highly grateful to Dr. Mahbubur Rahman, Senior Scientific Officer, Institute of Food Science and Technology, BCSIR, Dhanmondi, Dhaka, for his cordial cooperation and valuable help in biochemical analysis of the fishes.

\section{References}

Ahmad K and Hassan N. 1983. The Nutrition survey of rural Bangladesh, 1981-1982. $2^{\text {nd }}$ edn. University of Dhaka, Bangladesh. Institute of Nutrition and Food Science.

Andrew AE. 2001. Fish Processing Technology. University of IIorin Press, Nigeria.pp.7-8

Azam K, Basher MZ, Asaduzzaman M, Hossain MH and Ali MY. 2003. Biochemical quality assessment of fourteen selected dried fishes. Univ. j. zool. Rajshahi Univ. 22: 23-26.

Bhattacharyya SK, Vandyopadhway JK and Chattopadhyay AK. 1985. Improved dried product on blanching Gudusia chapra prior to sun drying. In: Harvest and post-harvest technology of fish. Society of Fish Technologists (India). p. 531.

Cocks LV and van Reda C. 1966. Laboratory Handbook for Oil and Fats Analysts. Academic Press, London. 88 pp. CSIR. 1962. Fish and Fisheries raw materials, India, vol. IV, p. 132. 
Darnton-Hill I, Hassan N, Karim R and Duthie MR. 1988. Tables of nutrient composition of Bangladeshi foods. English version with particular emphasis on vitamin A content. Helen Keller International, Dhaka, Bangladesh.

FAO. 1991. Fish for Food and Development. 49 pp.

Felts RA, Rajts F and Akhteruzzaman M. 1996. Small indigenous fish species culture in Bangladesh. IFADEP Sub-Project2. Development of Inland Fisheries. $41 \mathrm{pp}$.

Gheyasuddin S, Rahman A and Mumtazuddin M. 1979. Biochemical composition of shellfishes Bangladesh. Bangladesh J. Sci. Res., 2: 15-23.

Hels O, Hassan N, Tetens H and Thilsted SH. 2002. Food consumption energy and nutrient intake and nutritional status in rural Bangladesh: Changes from 1981-82 to 1995-96. Eur. j. Clon-Nutr. 57: 586-594.

Hoq E. 2004. Bangladesher Chhoto Mach (A book on small indigenous fish species of Bangladesh) by Enamul Hoq. Published by Graphic Sign, Mymensingh 2200. pp.81-84.

Hossain MA and Afroze S. 1991. Small Fisheries as Resource in Rural Bangladesh. Fishbyte. 9(2):15-18.

Hussain MM, Karim A, Alam Z, Islam MS, Khan A and Hossain A. 1992. Effect of pre-treatment on the drying of ghonia fish Labeo gonius in the open sun and in a solar tent. Bangladesh J. Zool. 20: 231-238.

Islam MA, Mohsin ABM, Bhuiyan AS and Absar N. 2003. Biochemical composition and nutritional value of Cirrhina reba (Hamilton, 1822) of Bangladesh. J. biosci. 11: 127-130.

Kamal D, Khan AN, Rahman MA and Ahamed F. 2007. Biochemical composition of some small indigenous freshwater fishes ffrom the river Mouri, Khulna, Bangladesh. Pak. J. Biol. Sci. 10(9):1559-1561

Kamaluddin A, Malek MA and Sanaullah M. 1977. Deshio khaddeer pustiman (in Bangla). Institute of Nutrition and Food Science, Dhaka University. pp. 1-20.

Mazumder D and Lorenzen K. 1999. Developing aquaculture of small native species (SNS) in Bangladesh: village level agroecological change and availability of SNS. Naga, ICLARM Quart. 22(3): 20-23.

Mazumder MSA, Rahman MM, Ahmed ATA, Begum M and Hossain MA. 2008. Proximate composition of some small indigenous fish species (SIS) in Bangladesh. Int. J. Sustain. Crop Prod. 3(4):18-23.

Mehlenbacher VC. 1960. Analysis of fats and oils. Garrard Press, Champaign, Illinois, $586 \mathrm{pp}$.

Minkin SE, Rahman MM and Halder S. 1997. Fish biodiversity, human nutrition and environmental restoration in Bangladesh. In: Openwater Fisheries of
Bangladesh (eds. Tsai C and Ali MY) pp. 75-88. The University Press Limited. Dhaka, Bangladesh.

Mollah AH, Rahman MS and Alam MT. 1998. Study on proximate chemical analysis of Bangladeshi freshwater fish Rita rita (Ham.) and seasonal variation of lipid, protein and related substances. Univ. j. zool., Rajshahi Univ. 17: 1-6.

Musa ASM. 2009. Nutritional quality components of indigenous freshwater fish species, Puntius stigma in Bangladesh. Bangladesh J. Sci. Ind. Res. 44(3): 367-370.

Nurullah M, Kamal M, Wahab MA, Islam MN, Ahsan CT and Thilsted SH. 2003. Nutritional quality of some small indigenous fish species of Bangladesh. In: Small indigenous species of fish in Bangladesh (MA Wahab, SH Thilsted and ME Hoq eds.), Bangladesh Agricultural University, Mymensingh, Bangladesh. pp. 151-158.

Naser MN, Chowdhury GW, Begum MM and Haque W. 2007. Proximate composition of prawn, Macrobrachium rosenbergii and shrimp, Penaeus monodon. Dhaka Univ. J. Biol. Sci. 16(1): 61-66.

Parween S, Dutta SK and Hossain MA. 1997. Post harvest management and utilization of SIS fishes including prawns. Proc. Seminar on Small Indigenous Species (SIS) of Fish Culture in Bangladesh, IFADEP Sp-2,12 Dec.,1996, Rajshahi University. pp.141-146.

Roos N, Islam MM and Thilsted SH. 2003. Animal source foods to improve micronutrient nutrition and human function in developing countries. J. Nutr. 133: 4021S-4026S.

Roos N, Wahab MA, Chamnan C and Thilsted SH. 2007. The role of fish in food-based strategies to combat vitamin A and mineral deficiencies in developing countries. $J$. Nutr. 137: 1106-1109.

Rubbi SF, Mujibar M, Khan AR, Jahan SS and Majeda B. 1987. Proximate composition and quality of some commercial species of fresh water fish. Bangladesh J. Sci. Res. 5(1): 1-20.

Saha SC. 1999. Studies on production, marketing and nutritional aspects of traditional dried products of freshwater small indigenous fish species. MS thesis. Department of Fisheries Technology, Bangladesh Agricultural University, Mymensingh. 101 pp.

Thilsted SH, Roos N and Hassan N. 1997. The role of small indigenous fish species in food and nutrition security in Bangladesh. Naga, ICLARM Quart. December: 13-15.

Manuscript received on 20 August 2011 and revised on 2 November 2011 